\title{
Total and free amino acid contents of popular rice varieties (Oryza sativa L.) consumed in the capital city of Sri Lanka
}

\author{
GVV Liyanaarachchi ${ }^{1 *}$, KRR Mahanama ${ }^{2}$, HPPS Somasiri ${ }^{1}$, PAN Punyasiri ${ }^{3}$ and JD Kottawa-Arachchi ${ }^{4}$ \\ ${ }^{I}$ Industrial Technology Institute, 363, Bauddhaloka Mawatha, Colombo 7. \\ ${ }^{2}$ Department of Chemistry, Faculty of Science, University of Colombo, Colombo 3. \\ ${ }^{3}$ Institute of Biochemistry, Molecular Biology and Biotechnology, University of Colombo, Colombo 3. \\ ${ }^{4}$ Tea Research Institute of Sri Lanka, Talawakelle.
}

\begin{abstract}
This study investigated the amino acid composition of eight local and three imported rice varieties frequently consumed by consumers in the capital of Sri Lanka. Investigation included twenty free amino acids (FAAs) analysed using liquid chromatography-tandem mass spectrometry (LCMS/MS) and sixteen protein bound amino acids analysed using high performance liquid chromatography with diode array detection (HPLC-DAD). The mean total amino acid (TAA) in rice ranged between $64.5 \pm 1.9 \mathrm{~g} / \mathrm{kg}$ and $96.0 \pm 5.1 \mathrm{~g} / \mathrm{kg}$ on dry basis (db). Ponni, Basmathi, Rathu Nadu and Fragrant rice which were parboiled varieties, reported the overall highest mean TAA contents while imported Ponni and Basmathi exhibited the highest mean essential amino acid (EAA) contents depicting high quality protein. Red rice varieties of Nadu, Kekulu and Kekulu Samba reported significantly $(\mathrm{p}<$ 0.05 ) higher mean TAA contents than their white counterpart varieties. The parboiled varieties; Rathu Nadu, Sudu Nadu, Keeri Samba and Samba reported the overall highest gamma amino butyric acid (GABA) contents $(0.9 \pm 0.3-5.0 \pm 1.7$ $\mathrm{mg} / 100 \mathrm{~g})$. Completely polished Sudu Kekulu reported the overall lowest mean TAA, EAA and GABA contents. Except for unanalysed tryptophan, findings revealed that disregarding the nutritional loss encountered during cooking irrespective of variety, consumption of approximately $100 \mathrm{~g}$ of raw rice (after cooking) three times a day will provide an average adult (of $50 \mathrm{~kg}$ body weight) more than $50 \%$ of the daily intake of essential individual amino acids recommended by the Food and Agricultural Organization (FAO).
\end{abstract}

Keywords: Essential amino acids, GABA, rice, Sri Lanka, total amino acids.

\section{INTRODUCTION}

Rice (Oryza sativa L.) is the dietary staple of more than half of the world's population, which significantly contributes to the daily nutritional requirement (Kennedy \& Burlingame, 2003).

As the dietary staple, rice accounts for approximately $45 \%$ of the total calorie intake and around $40 \%$ of the total protein requirement of an average Sri Lankan (Kennedy et al., 2003). The per capita consumption of rice fluctuated around $105 \mathrm{~kg}$ per year throughout the past three decades (Jayatissa et al., 2014). There are two major types of rice varieties mainly grown in the country termed short grain (Samba) and long grain (Nadu) among which the consumption of long grain predominates with an average of $81 \%$ where as the short grain accounts for only around $19 \%$ of the total rice consumption. Rice is also categorised as parboiled or raw (Kekulu) based on the method of processing. The percentage consumption of parboiled rice $(54.3 \%)$ surpasses the percentage of nonparboiled rice consumed in the country. The selection of the variety for consumption is significantly influenced by the taste, aroma, texture and ease of cooking while the appearance characteristics such as colour, shape, size and cleanliness are among the secondary important factors that can be attributed to the selection of the variety

"Corresponding author (vimarshi@iti.lk; (10 https://orcid.org/0000-0001-9303-3589)

This article is published under the Creative Commons CC-BY-ND License (http://creativecommons.org/licenses/by-nd/4.0/). This license permits use, distribution and reproduction, commercial and non-commercial, provided that the original work is properly cited and is not changed in anyway. 
(Rambukwella et al., 2017). Owing to the consumption habits related to urbanisation and ethnic differences, significant variations in rice consumption by varieties have been reported (Department of census and statistics, 2016). According to the survey report, Sudu Kekulu, Sudu Kekulu Samba, Rathu Kekulu, Rathu Kekulu Samba, Samba, Rathu Nadu, Sudu Nadu and Basmathi were among the highly consumed rice varieties in the country.

As the second most abundant nutrient next to carbohydrates, protein plays a significant role in determining the functional properties, texture, pasting capacity and the sensory characteristics of rice (Lyon et al., 1999; Martin \& Fitzgerald, 2002; Xie et al., 2008). Since amino acids are the building blocks of proteins, from the nutritional perspective, the amino acid composition of rice becomes important in defining the characteristics related to the protein quality of rice. Besides the protein- bound amino acids present as major components, minor amounts of free amino acids (FAAs) are also found in rice. The apparent relationship reported with the levels of FAAs in food to the organoleptic characteristics has inspired the scientific research towards analysis of FAA composition in food (Nishimura \& Kato, 1988; Gunlu \& Gunlu, 2014; Kasumyan, 2016).

In addition to the proteogenic FAA pool, rice is also enriched with gamma-aminobutyric acid (GABA) which is a non proteogenic amino acid that aids regulation of several physiological functions such as neurotransmission (Jakobs et al., 1993), diuretic effects, inducing relaxation effects (Mody et al., 1994), reducing blood pressure (Inoue et al., 2003), controlling diabetic conditions (Imam et al., 2012) and inhibiting cancer cell proliferation (Park \& Oh, 2007). Hence, from the nutritional aspect, the investigation of GABA levels present in rice becomes inevitably important.

The aim of the present study was to determine the levels and the variation patterns of the amino acid profiles including GABA present in rice consumed by the local population of the major city of the country, with a view to provide reference for selection of varieties to be included in the food consumption patterns and to identify varieties to be popularised in future breeding programmes.

\section{METHODOLOGY}

\section{Chemicals and reference standards}

The analytical reference standards of amino acids including GABA with purity $>98 \%$ were obtained from Sigma Aldrich Chemicals, St. Louis, MO and the internal standard; L-theanine with purity $>98 \%$ was purchased from Baxter Smith Labs, USA. The other chemicals used including the solvents were of either LCMS grade or HPLC grade purchased from Sigma Aldrich Chemicals, Switzerland. The derivatising agents, o-phthalaldehyde 3-mercaptopropionic acid (OPA-3MPA), 9-Fluorenylmethoxycarbonyl chloride (FMOC) and borate buffer ( $\mathrm{pH}-10.2)$ were purchased from Agilent Technologies, USA.

Table 1: Basic characteristics and the average monthly consumption of rice per person for the varieties used in the study

\begin{tabular}{llcccc}
\hline Variety & Grain size & Ecotype & $\begin{array}{c}\text { Parboiled/ } \\
\text { non-parboiled }\end{array}$ & $\begin{array}{c}\text { Pericarp } \\
\text { colour }\end{array}$ & $\begin{array}{c}\text { Local/ } \\
\text { imported }\end{array}$ \\
\hline Rathu Kekulu Samba & Short grain & indica & Non-parboiled & Red & Local \\
Sudu Kekulu Samba & Short grain & indica & Non-parboiled & White & Local \\
Rathu Kekulu & Long grain & indica & Non-parboiled & Red & Local \\
Sudu Kekulu & Long grain & indica & Non-parboiled & White & Local \\
Rathu Nadu & Long grain & indica & Parboiled & Red & Local \\
Sudu Nadu & Long grain & indica & Parboiled & White & Local \\
Keeri Samba & Short grain & indica & Parboiled & White & Local \\
Samba & Short grain & indica & Parboiled & White & Local \\
Basmathi & Long grain & indica & Parboiled & White & Imported \\
Ponni & Short grain & indica & Parboiled & White & Imported \\
Fragrant Rice & Short grain & indica & Parboiled & White & Imported \\
\hline
\end{tabular}

na: data not available

* Percentage of average monthly consumption per person out of the total rice consumed was adapted from the household income and expenditure survey (Department of Census and statistics, 2016) 


\section{Grain samples}

Eight locally grown varieties: Rathu Kekulu Samba, Sudu Kekulu Samba, Rathu Kekulu, Sudu Kekulu, Rathu Nadu, Sudu Nadu, Keeri Samba, Samba and three imported rice varieties; Basmathi, Ponni, fragrant rice, which are highly consumed and popular among the Sri Lankan consumers were selected for the study (Table 1). These varieties included rice with different grain characteristics. In addition, the investigated rice included varieties which were subjected to different post harvest treatments of milling and parboiling.

Representative six samples from each variety collected from the leading supermarkets and the open economic centres located at Nugegoda, Narahenpita, Kirulapona, Pettah, Dematagoda, and Wellawatta representing the Colombo municipal area were analysed.

\section{Sample preparation for FAA analysis including GABA}

The finely ground (IKA-MF 10 basic Microfine grinder drive) uncooked rice samples were sieved through a $0.3 \mathrm{~mm}$ sieve prior to analysis. The FAAs in rice were extracted using the validated method described in the previous study carried out by the authors (Liyanaarachchi et al., 2018). The summary of the method performance characteristics of FAA analysis are given as a supplementary table. For the FAA analysis including GABA, $100 \mu \mathrm{L}$ from each IS; L-theanine and L-Nor (concentration $100 \mathrm{~g} / \mathrm{L}$ ) were added to $0.2 \mathrm{~g}$ of finely ground and sieved rice samples. The extraction of FAAs was performed by shaking the weighed rice sample with $10 \mathrm{~mL}$ of methanol:water $(40: 60, \mathrm{v} / \mathrm{v})$ mixture for $10 \mathrm{~min}$ in a mechanical shaker at $125 \mathrm{rpm}$ followed by centrifugation at $15,000 \mathrm{rpm}$ for $10 \mathrm{~min}$. After filtration

Table 2: Method conditions for LC-MS/MS analysis

\begin{tabular}{|c|c|c|c|c|c|c|c|c|c|}
\hline Amino Acid & $\begin{array}{c}\mathrm{RT} \\
(\mathrm{min})\end{array}$ & ESI Mode & $\begin{array}{c}\mathrm{Q}^{*} \\
(\mathrm{Da})\end{array}$ & $\begin{array}{c}\text { Q1 } \\
(\mathrm{Da})\end{array}$ & $\begin{array}{c}\text { Q2 } \\
(\mathrm{Da})\end{array}$ & $\begin{array}{l}\text { DP } \\
(\mathrm{V})\end{array}$ & $\begin{array}{l}\text { EP } \\
(\mathrm{V})\end{array}$ & $\begin{array}{l}\text { CE } \\
(\mathrm{V})\end{array}$ & $\begin{array}{c}\text { CXP } \\
(\mathrm{V})\end{array}$ \\
\hline Asn & 3.96 & Pos & 133 & 116 & 74 & 31,41 & 10 & 13,25 & 8,22 \\
\hline Phe & 7.34 & Pos & 166 & 120 & 103 & 31 & 10 & 21,35 & 12,28 \\
\hline Val & 4.49 & Pos & 118 & 72 & 55 & 36 & 10 & 13,29 & 10,6 \\
\hline Lys & 3.69 & Pos & 147 & 130 & 84 & 16,21 & 10 & 13,23 & 6,8 \\
\hline Ala & 4.01 & Pos & 90 & 44 & - & 20 & 10 & 19 & 6 \\
\hline Tyr & 4.88 & Pos & 182 & 165 & 136,123 & 46,51 & 10 & $19,13,25$ & 6,16 \\
\hline His & 3.73 & Pos & 156 & 110 & 93 & 41 & 10 & 17,31 & 14,8 \\
\hline Trp & 9.46 & Pos & 205 & 188 & 146 & 41 & 7 & 15,24 & 9,39 \\
\hline Ser & 3.94 & Pos & 106 & 60 & 42 & 31 & 10 & 15,31 & 6,4 \\
\hline Asp & 3.99 & Pos & 134 & 88 & 70 & 26,36 & 10 & 13,25 & 14,6 \\
\hline Met & 4.68 & Pos & 150 & 133 & 104 & 21 & 10 & 13,15 & 8,12 \\
\hline Glu & 4.06 & Pos & 148 & 102 & 84 & 21 & 10 & 15,23 & 4,12 \\
\hline Pro & 4.27 & Pos & 116 & 70 & - & 8 & 7 & 23 & 9 \\
\hline Gly & 3.92 & Pos & 76 & 30 & - & 46 & 10 & 17 & 8 \\
\hline Ile & 5.45 & Pos & 132 & 86 & 69 & 40 & 7 & 15,24 & 14,9 \\
\hline Leu & 6.15 & Pos & 132 & 86 & 69 & 36 & 10 & 23 & 8,20 \\
\hline Arg & 3.74 & Pos & 175 & 116 & 70,60 & $46,56,41$ & 10 & $19,35,19$ & $6,8,6$ \\
\hline Thr & 4.03 & Pos & 120 & 74 & 56 & 46,86 & 10 & 15,23 & 8,6 \\
\hline Gln & 2.84 & Pos & 147 & 84 & 102 & 21,31 & 10 & 23,19 & 6,12 \\
\hline GABA & 3.05 & Pos & 104 & 69 & 87 & 31,26 & 10 & 25,5 & 6 \\
\hline Nor (IS) & 6.00 & Pos & 132 & 86 & 68 & 31 & 10 & 25 & 8 \\
\hline Theanine (IS) & 4.01 & Pos & 175 & 84 & 158 & 35 & 10 & 27,16 & 24,39 \\
\hline
\end{tabular}

RT: Retention time; ESI: Electron spray ionisation; Q*: Parent mass; Q1: Quantifier mass; Q2: Qualifier mass; DP: Declustering; potential; CE: Collision energy; EP: Exit potential; CXP: Collision cell exit potential

Asp: Aspartic acid; Glu: Glutamic acid; Asn: Asparagine; Ser: Serine; Gln: Glutamine; His: Histidine; Gly: Glycine; Thr: Threonine; Arg: Arginine; Ala: Alanine; Tyr: Tyrosine; Val: Valine; Met: Methionine; Lys: Lysine; Trp: Tryptophan; Phe: Phenylalanine; Ile: Isoleucine; Leu: Leucine; Pro: Proline; Nor: Norleucine IS: Internal standard; GABA: Gamma amino butyric acid 
through $0.22 \mu \mathrm{m}$ nylon syringe filter, the supernatant solution was subjected to LC-MS/MS analysis.

The moisture content of the rice samples were determined by oven drying the rice at $130{ }^{\circ} \mathrm{C}$ for $2 \mathrm{~h}$ as specified in the ISO 712 method (ISO 712, 2009).

\section{Instrumentation and analytical LC-MS/MS method for FAA analysis}

The detection of FAAs was performed using an Eksigent Expert Ultra LC 100 XL (Eksigent, Netherlands) UPLC system, coupled to an ABSciex (QTrap) 4500 series triple quadrupole linear ion trap mass spectrometer (Sciex, USA) in electro spray ionisation (ESI) with multiple reaction monitoring (MRM) transitions (Table 2). The ion spray voltage was set at $5500 \mathrm{~V}$ while the source temperature was maintained at $500^{\circ} \mathrm{C}$. Both the nebulizer and the heater gas were operated at $50 \mathrm{kPa}$.
The FAAs were separated on an Agilent Zorbax Eclipse C18 (4.6 x $100 \mathrm{~mm}, 5$ micron) column using gradient elution within $12.5 \mathrm{~min}$ (Figure 1a). The gradient elution started with $90 \%$ A for 0 min; ramped to $30 \%$ B within next $6.5 \mathrm{~min}$ at a flow rate of $0.4 \mathrm{~mL} / \mathrm{min}$; ramped to $100 \% \mathrm{~B}$ in $7 \mathrm{~min}$ and was kept at $100 \% \mathrm{~B}$ till $8 \mathrm{~min}$; ramped to $90 \% \mathrm{~A}$ in $8.5 \mathrm{~min}$ and kept at $90 \%$ till $12.5 \mathrm{~min}$ at a flow rate of $0.4 \mathrm{~mL} / \mathrm{min}$. The column was operated at $40{ }^{\circ} \mathrm{C}$ throughout the total runtime. Data acquisition and processing were performed using Analyst software (version 1.6.2) from Sciex Corporation, USA.

\section{Sample preparation for TAA analysis}

To $0.2 \mathrm{~g}$ of the sieved rice sample placed inside a screw capped glass tube, of $5.00 \mathrm{~mL}$ of the hydrolysis mixture ( $6 \mathrm{~mol} / \mathrm{L} \mathrm{HCI}$ containing $1 \mathrm{~g}$ of phenol per liter) was added. The sample after vortexing for $5 \mathrm{~min}$ was placed inside a drying oven set at $110^{\circ} \mathrm{C}$ for $22 \mathrm{~h}$ to complete the

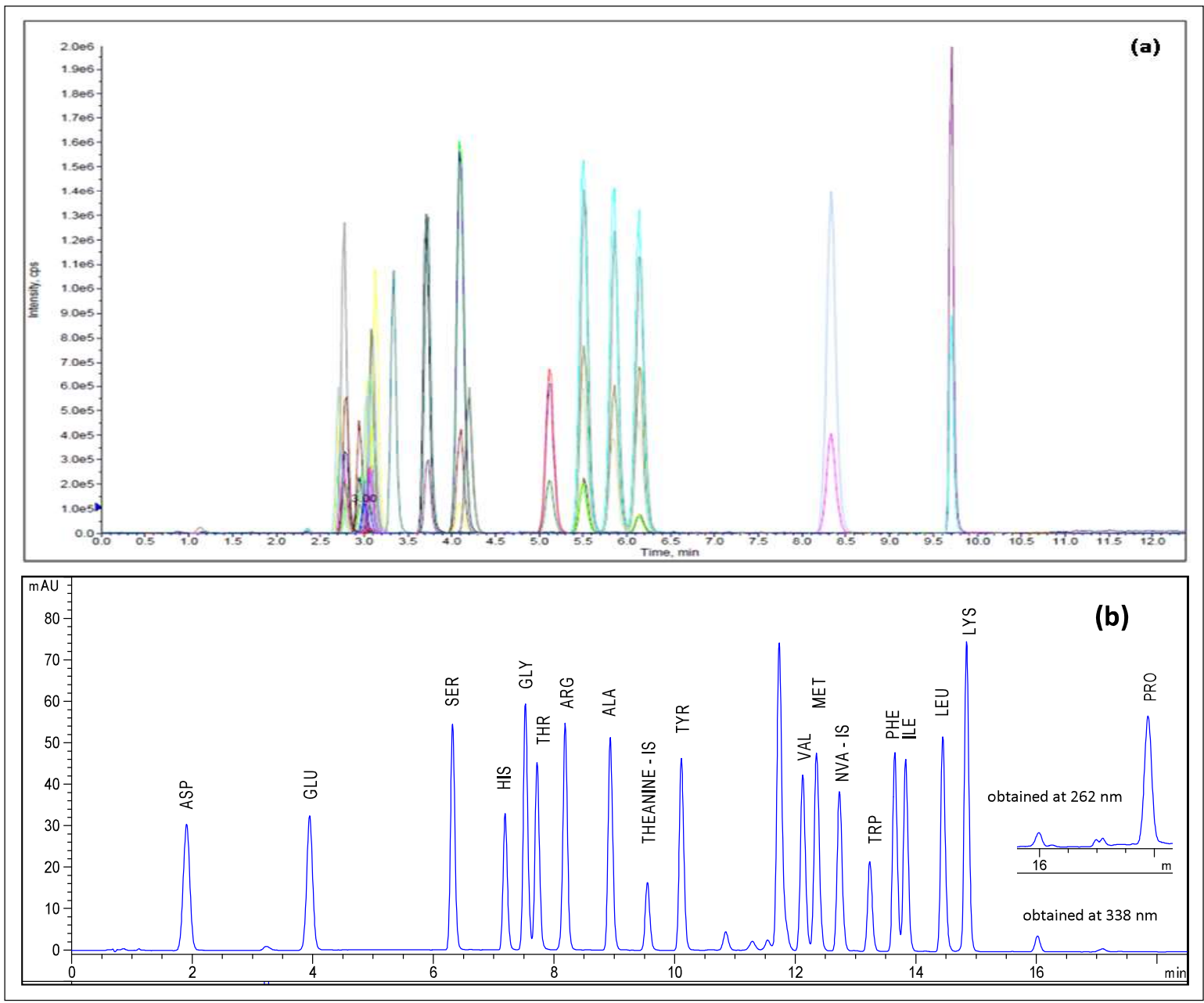

Figure 1: a) LC-MS/MS chromatogram of amino acid standards, b) HPLC chromatogram of amino acid standards 
hydrolysis (ISO 13903). In order to minimise building up of pressure due to the evolution of gaseous substances, the screw capped tube containing the hydrolysis mixture was tightened only after it was kept open for an hour inside the oven. After completion of the hydrolysis, the mixture was transferred to an ice bath and the $\mathrm{pH}$ of the hydrolysed mixture was adjusted to 2.2 using $10 \mathrm{M}$ sodium hydroxide solution. Final $\mathrm{pH}$ adjustments were done with $1 \mathrm{M}$ sodium hydroxide solution while keeping the temperature of the solution below $40{ }^{\circ} \mathrm{C}$. The $\mathrm{pH}$ adjusted solution was transferred to a $25 \mathrm{~mL}$ volumetric flask of $100 \mu \mathrm{L}$ from each $50 \mathrm{nmol} / \mathrm{L}$ IS's L-Nva and L-theanine. The resulting solution was made up to the mark with ultra pure water acidified to $\mathrm{pH} 2.2$ with $\mathrm{HCl}$.

\section{Instrumentation and analytical HPLC method for TAA analysis}

The analysis was performed using an Agilent 1100 HPLC system (Agilent Technologies, Palo Alto, CA) which consisted of a diode array detector (DAD) (G1321A) and a programmable auto sampler (G1313A).
The chromatographic separation of amino acids was achieved using an Agilent Zorbax Eclipse AAA column (4.6 mm x $150 \mathrm{~mm}, 5$ micron) with gradient elution (Figure 1b). The gradient elution started with $100 \% \mathrm{~A}$ for $1.9 \mathrm{~min}$; ramped to $57 \% \mathrm{~B}$ within next $18.1 \mathrm{~min}$; ramped to $100 \% \mathrm{~B}$ in $18.6 \mathrm{~min}$ and kept at $100 \% \mathrm{~B}$ till $22.3 \mathrm{~min}$; then ramped to $100 \% \mathrm{~A}$ in $23.2 \mathrm{~min}$ and kept with $100 \%$ A till 26 min. The column was operated at $40{ }^{\circ} \mathrm{C}$ and the flow rate of the method was set at $2 \mathrm{~mL} / \mathrm{min}$ throughout the runtime (Henderson et al., 2000). The automated pre-column derivatisation with $o$-phthalaldehyde 3-mercaptopropionic acid OPA-3MPA and fluorenylmethyloxycarbonyl chloride (FMOC) was performed prior to injection with a programmed injector using the injector settings as described in Table 3 (Henderson et al., 2000). The primary amino acids which were derivatised using OPA-3MPA were monitored at $338 \mathrm{~nm}$ while the secondary amino acid, Pro, which was derivatised using FMOC was monitored at $262 \mathrm{~nm}$ using the DAD detector. Agilent Chemstation software version B.04.03 was used for the data acquisition and analysis.

Table 3: Injector programme for pre-column online derivatisation for TAA analysis

\begin{tabular}{|c|c|c|c|c|}
\hline Line & Function & Amount & Vial position & Reagent \\
\hline 1 & Draw & $2.5 \mu \mathrm{L}$ & 1 & borate buffer \\
\hline 2 & Draw & $0.5 \mu \mathrm{L}$ & 7 onwards* & sample \\
\hline 3 & Mix & $\begin{array}{l}3.0 \mu \mathrm{L} \text { in air } \\
\text { max speed } \\
2 \text { times }\end{array}$ & & \\
\hline 4 & Wait & $0.5 \mathrm{~min}$ & & \\
\hline 5 & Draw & $0 \mu \mathrm{L}$ & 2 & Water - (needle wash using uncapped vial) \\
\hline 6 & Draw & $0.5 \mu \mathrm{L}$ & 3 & OPA \\
\hline 7 & Mix & $\begin{array}{l}3.5 \mu \mathrm{L} \text { in air } \\
\text { max speed } \\
6 \text { times }\end{array}$ & & \\
\hline 8 & Draw & $0.5 \mu \mathrm{L}$ & 4 & FMOC \\
\hline 9 & Mix & $\begin{array}{l}4.0 \mu \mathrm{L} \text { in air } \\
\text { max speed } \\
6 \text { times }\end{array}$ & & \\
\hline 10 & Draw & $0 \mu \mathrm{L}$ & 2 & Water- (needle wash using water in uncapped vial \\
\hline 11 & Draw & & 6 & acetonitrile \\
\hline 12 & Draw & $32 \mu \mathrm{L}$ & 5 & water (capped vial) \\
\hline 13 & Mix & $\begin{array}{l}18 \mu \mathrm{L} \text { in air } \\
\text { max speed } \\
2 \text { times }\end{array}$ & & \\
\hline 14 & Inject & & & \\
\hline
\end{tabular}

TAA: Total amino acids; * vial position of the sample in the tray 


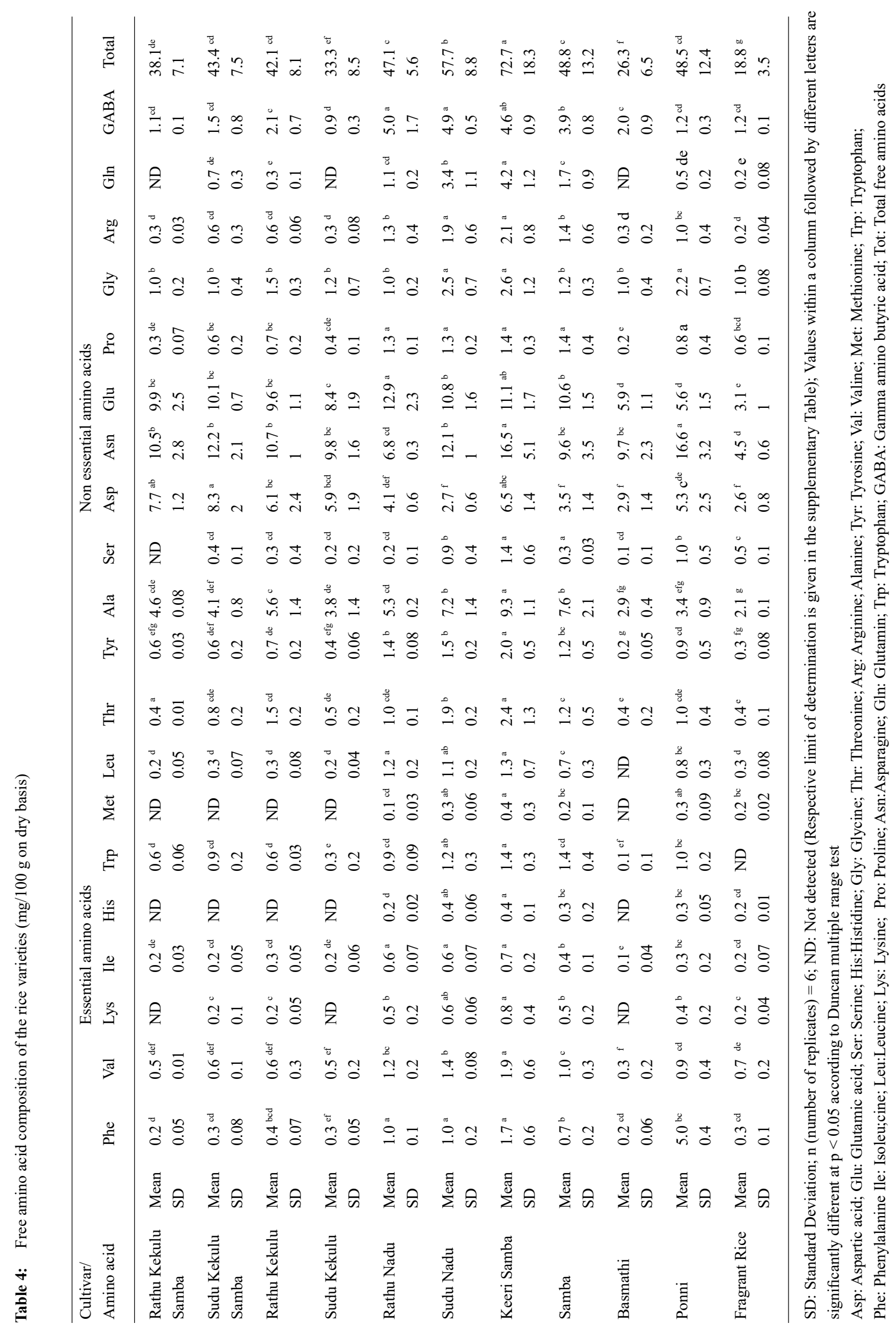




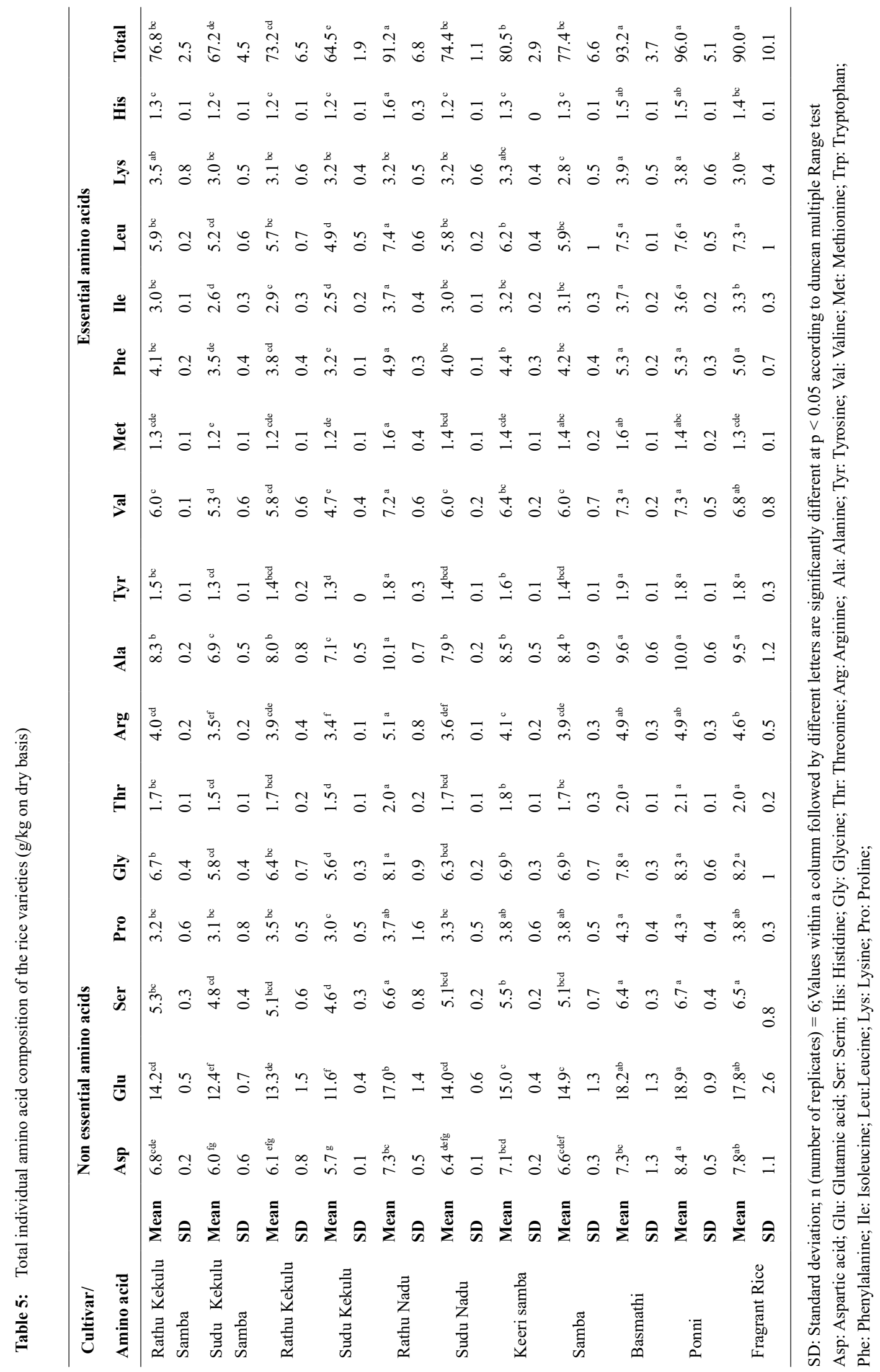


The two methods incorporated for the analysis of amino acids were validated as per the guidelines described in FDA, AOAC International and Eurachem Method validation guidelines (Eurachem, 2014; AOAC, 2002) and found in compliance with the international method validation requirements (Supplementary Table).

The individual levels of the free and total amino acids present in the samples were quantified using the calibration plots constructed by fitting the analyte concentrations of the calibrators versus the peak area ratios of the analyte to IS with line regression over six calibration levels.

\section{Statistical evaluation}

The statistical analysis was performed using the statistical software package, SAS for Windows V 9.1 (SAS Institute Inc., NC, USA). The amino acids were quantified in six replicates from each of the varieties and were analysed using ANOVA, Duncan multiple range test (DMRT) analysis. The level of significance was $p<0.05$.

\section{RESULTS AND DISCUSSION}

\section{Variation in FAA composition}

Table 4 summarises the mean individual and total free amino acid (TFAA) contents observed in the studied rice varieties. According to the FAA profiles, asparagine, glutamic acid, aspartic acid and alanine were among the amino acids with the highest content while methionine and histidine were the least present. The mean TFAA content ranged between $18.8 \pm 3.5$ and $72.7 \pm 18.3$ $\mathrm{mg} / 100 \mathrm{~g}$ of rice $(\mathrm{db})$. The observed TFAA levels are comparable to the findings made by Kamara et al. (2010) and Komatsuzaki et al. (2007) for rice varieties found in Asia. Further, it was also found that the TFAA composition observed in rice is significantly lower than the FAA composition reported for other cereal grains such as wheat, rye, barley (Nagaoka, 2005; Mustafa et al., 2007) and corn (Culea et al., 2015).

Significant differences in mean values obtained for individual and TFAA content in rice varieties were observed. The highest mean TFAA level was observed in Keeri Samba $(72.7 \pm 18.3 \mathrm{mg} / 100 \mathrm{~g})$ variety while the lowest was found in the fragrant rice with an average value of $18.8 \pm 3.5 \mathrm{mg} / 100 \mathrm{~g}$. Unlike the TAA compositions, no marked influence was observed on TFAA levels from either the processing techniques or grain characteristics. Influence caused by the environmental and the agronomic practices could be attributed for these variations in the composition of amino acids observed for a particular cultivar (Juliano \& Villareal, 1993; Kamara et al., 2010).

The GABA content also significantly varied among the cultivars ranging from $0.9 \pm 0.3-5.0 \pm 1.7 \mathrm{mg} / 100 \mathrm{~g}(\mathrm{db})$ (Table 4). The GABA levels observed in the experimented indica rice varieties were greater than the japonical javanica and indica varieties reported by Kamara et al., (2010). However, comparable GABA levels and genotype variations have been observed in few brown indica rice varieties cultivated in China (Shen et al., 2015) and several rice varieties grown in Thailand (Karladeea \& Suriyonga, 2012).

The highest GABA content was detected in Rathu $N a d u$ and Sudu Nadu while the lowest amount was observed in Sudu Kekulu rice. Interestingly, all the varieties which reported the highest were parboiled rice varieties. The enzymatic activities induced during the germination step carried out prior to boiling and the heating step involved with the production of parboiled rice, which accounts for considerable increment in the GABA content, significantly contributes towards the raised nutritive value of parboiled rice over the nonparboiled varieties (Liu et al, 2005). In addition, the inward diffusion during the parboiling steps which results in the retention of minerals and water-soluble vitamins (Battacharya, 1985) accounts for the comparatively higher nutritive value in parboiled rice relative to the milled rice. Therefore, these findings in conjunction with the health promoting activity associated with GABA in reducing diabetes (Imam et al., 2012), high blood pressure (Inoue et al., 2003) and reported anti cancer activity (Park \& Oh, 2007) can inevitably be utilised in driving the local food consumption patterns towards consumption of parboiled rice. Further, these findings on the genetic diversity of the ability of each rice variety to synthesise GABA will provide guidance for the selection of varieties to be popularised and in the manipulation of desirable traits in breeding to improve nutritional and functional properties of rice.

Asparagines present in free form together with soluble sugars are reported to be associated with the formation of acrylamide (Curtis \& Halford, 2016), a compound which is classified as a group 2A carcinogen declared by the International Agency for Research on Cancer (IARC, 1994). Among the varieties, the mean asparagine content was found highest in Ponni (16.6 \pm $3.2 \mathrm{mg} / 100 \mathrm{~g})$ and Keeri Samba $(16.5 \pm 5.1 \mathrm{mg} / 100 \mathrm{~g})$ $(\mathrm{db})$ varieties, while the lowest was reported in fragrant rice. As given in Table 4, the mean asparagine content detected among the rice varieties ranged between $4.5 \pm$ 
$0.6-16.6 \pm 3.2 \mathrm{mg} / 100 \mathrm{~g}(\mathrm{db})$. Curtis et al. (2016) in their study done with wheat have established that if the wheat grain contains $25.08 \mathrm{mg} / 100 \mathrm{~g}$ of asparagine, the acrylamide-forming potential will be $1.69 \mu \mathrm{g} / \mathrm{kg}$. This is well below the benchmark levels set by the European Commission for rice-based products, which is $150 \mu \mathrm{g} /$ $\mathrm{kg}$ (EU 2017/2158). The asparagine values detected in the rice varieties in the present study were significantly lower than the contents detected in other cereal grains such as rye, wheat, barley and maize (Fredriksson et al., 2004; Zilic et al., 2017). Therefore, during food processing, acrylamide formation promoted by heating is comparatively lower in rice compared to the other cereals reported with high free asparagine contents suggesting rice as a safer option over the rest of the cereals.

\section{Variation in TAA composition}

The summary of mean individual and mean TAA levels observed in the rice cultivars under study are given in Table 5. Glutamic acid was the most predominant amino acid which ranged between $11.6 \pm 0.4-18.9 \pm$ $0.9 \mathrm{~g} / \mathrm{kg}(\mathrm{db})$. Comparatively higher levels of aspartic acid, glycine, alanine, aeucine, valine and serine were found in the rice cultivars while hydroxyproline, phenylalanine, isoleucine, methionine, glutamine and leucine were the least present. The mean TAA content in the studied cultivars ranged between $64.5 \pm 1.9 \mathrm{~g} / \mathrm{kg}$ and $96.0 \pm 5.1 \mathrm{~g} / \mathrm{kg}(\mathrm{db})$ of rice.

Several studies (Park et al., 2009; Rita et al., 2009; Ning et al, 2010; Liu et al., 2017) have reported similar compositions of glutamic acid, aspartic acid and valine contents in rice. However, comparatively higher levels of alanine and glycine were found in the investigated rice varieties.

Significant differences were observed in the mean values obtained for the individual and TAA content (Table 5). The variations observed for mean TAA content, total mean essential amino acids (EAA) and total mean non essential amino acid levels (NEAA) among the varieties are depicted in Figure 2. The total essential amino acids (EAA) included the eight indispensable amino acids, namely, valine, lysine, leucine, isoleucine, methionine, histidine, threonine and phenylalanine, while the total non essential amino acid levels (NEAA) is indicative of the sum of glutamic acid, aspartic acid, proline, alanine, glycine, serine, arginine and tyrosine.

The highest mean TAA content was detected in Ponni followed by Basmathi, Rathu Nadu and fragrant rice varieties, whereas the lowest TAA levels were observed in the Sudu Kekulu variety. All the cultivars reporting the highest TAA contents were parboiled varieties depicting the fact that in terms of nutritive value with respect to protein content, the parboiled varieties are superior over the non-parboiled varieties in the market. Another key finding was that out of the four with the highest mean TAA levels, three of the rice varieties, namely, Ponni, Basmathi and fragrant rice were imported whereas Red $N a d u$ being the only local variety. Moreover, the levels of lysine, the limiting amino acid in cereal crops considered as an indicator of the protein quality was highest in the imported rice varieties Basmathi and Ponni with the least in the samba variety. Proline, the amino acid which accounts for the popcorn smell of rice was highest in the aromatic rice varieties Ponni, Basmathi and fragrant rice (Table 5).

In all experimented varieties, the mean TAA content in rice with the red pericarp were significantly higher than the rice varieties with the white pericarp. For example, as given in the Table 5, the mean TAA content in Rathu Nadu, Rathu Kekulu and Rathu Kekulu Samba were significantly higher compared to Sudu Nadu, Sudu Kekulu and Sudu Kekulu Samba, respectively. In unpolished rice, protein is more concentrated in the aleurone layer, the embryo, and the subaleurone layer of the endosperm compared to the deeper starchy endosperm (Ellis et al., 1987). Lower values in white rice varieties could possibly be due to the removal of significant amounts of amino acids present in the pericarp of rice during milling.

Figure 3 depicts the comparison of mean TAA content reported in the experimented varieties against the recommended daily intake for each individual essential amino acids (WHO/FAO), 2007. The levels present in each rice variety were calculated considering the consumption of three meals per day with an average of $100 \mathrm{~g}$ of raw rice per meal after cooking, disregarding the losses in amino acids encountered during cooking. Consumption of the above mentioned amount fulfills the nutritional requirement of the essential amino acid valine (Figure 3). However, the mean content of lysine, methionine, threonine and histidine in the experimented varieties was below the recommended daily intake. However, inclusion of Rathu Nadu, Ponni and Basmathi varieties in the meals thrice a day will provide the daily recommended allowance of leucine, isoleucine, valine and phenylalanine (WHO/FAO), 2007. Hence, in conjunction with the findings of the close relationship with rapid increase of fast food consumption and obesity and diabetes among the young generation in the country, the findings outlined in the study can be utilised by nutritionists and policy makers to come up with timely 
interventions for redefining the consumption patterns of the people and in the popularisation of rice consumption for three meals per day in driving the generations towards a healthy nation. Further, as a remedial measure in combating malnutrition in the country, findings of this study can be utilised by the rice breeders in identification of traits in breeding varieties rich with amino acids such as lysine.

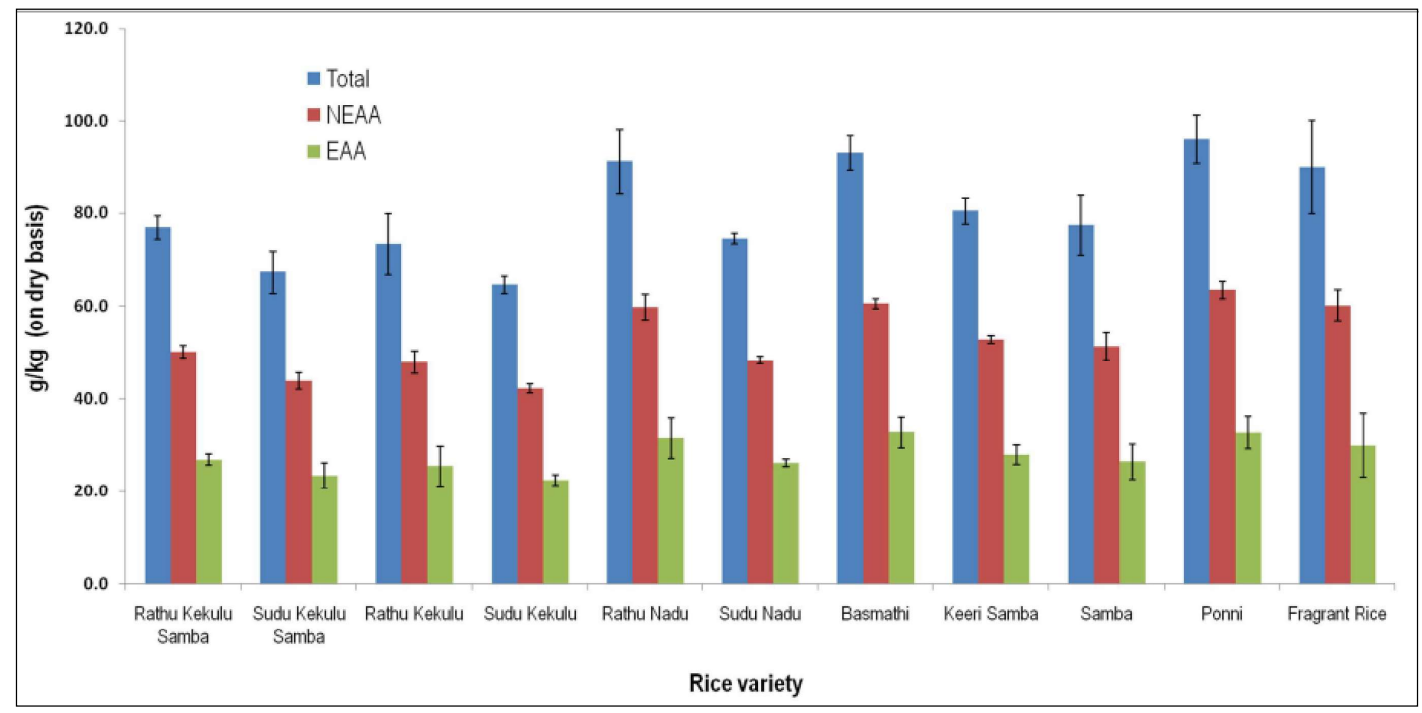

Figure 2: Variation in mean total amino acid content, essential amino acid (EAA) content and non-essential amino acid (NEAA) content in rice expressed as $\mathrm{g} / \mathrm{kg}$ (on dry basis)

Number of replicates $(n)=6$

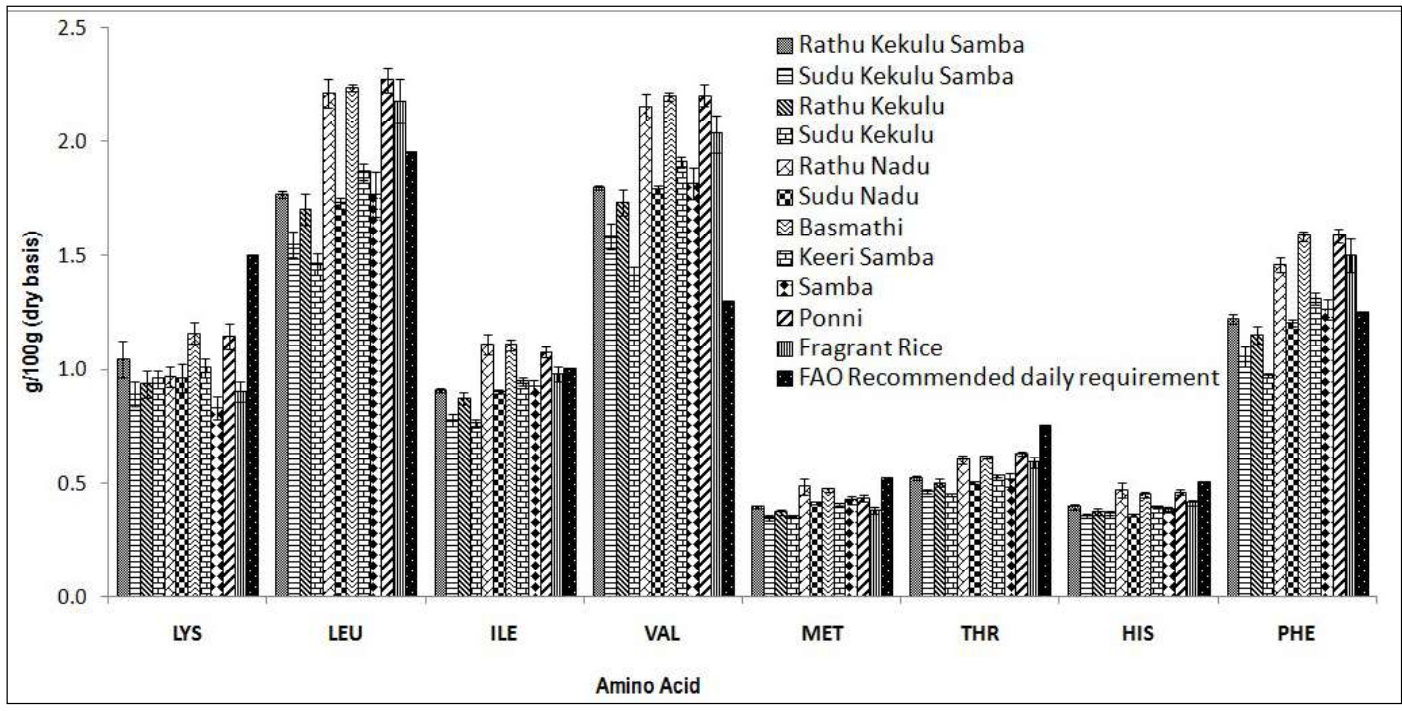

Figure 3: Comparison of essential individual mean amino acid levels* of rice varieties against the daily recommended allowance specified by the Food and Agricultural Organization (FAO) for an average adult of $50 \mathrm{~kg}$ body weight

* The levels were calculated considering the consumption of an average of $100 \mathrm{~g}$ of raw rice per meal thrice a day after cooking, disregarding the losses encountered during cooking; number of replicates $(n)=6$ 


\section{CONCLUSION}

Owing to the wide genetic diversity and the processing techniques employed, significant variations in individual FAAs including GABA as well as TFAA levels were observed among the studied varieties.

Except for the unanalysed tryptophan, findings revealed that, disregarding the nutritional loss encountered during cooking and irrespective of variety, for an average adult of $50 \mathrm{~kg}$ body weight, consumption of approximately $100 \mathrm{~g}$ of raw rice per meal after cooking, three times a day will provide more than $50 \%$ of the standard daily requirement of essential individual amino acids recommended by the Food and Agriculture Organization (FAO).

\section{Conflict of Interest Statement}

We wish to confirm that there are no known conflicts of interest associated with this publication.

\section{Acknowledgements}

The authors gratefully acknowledge the financial support granted by the Sri Lankan Treasury to the Industrial Technology Institute (TG 18/165).

\section{REFERENCES}

AOAC (2002). Official methods of analysis of the association of official analytical chemists international. Guidelines for single laboratory validation of chemical methods for dietary supplements and botanicals. Maryland, USA.

Bhattacharya K.R. (1985). Parboiling of rice. In: Rice Chemistry and Technology (ed.B.o. Juliano), pp. 289-348 $2^{\text {nd }}$ edion. The American Association of Cereal Chemists, St Paul, MI, USA.

Commission Regulation (EU) 2017/2158. (2017). Establishing mitigation measures and benchmark levels for the reduction of the presence of acrylamide in food.

Culea M., Scrob S., Suvar S., Podea P., Has I. \& Muste S. (2015). Determination of amino acids in corn seed by gas chromatography-mass spectrometry. Analytical Letters $\mathbf{4 8}$ (1): 37-46. DOI: https://doi.org/10.1080/00032719.2014.930869

Curtis T.Y. \& Halford N.G. (2016). Reducing the acrylamideforming potential of wheat. Food and Energy Security 5: 153-164. DOI: https://doi.org/10.1002/fes3.85

Ellis J.R., Gates P.J. \& Boulter D. (1987). Storage protein deposition in the developing rice caryopsis in relation to transport $\mathrm{t}$ tissues. Annals of Botany 60: 663-670. DOI: https://doi.org/10.1093/oxfordjournals.aob.a087497
EURACHEM Guide (2014). The Fitness for Purpose of Analytical Methods: A Laboratory Guide to Method Validation and Related Topics, 1st edition. Teddington: Eurachem.

Fredriksson H., Tallving J., Rosen J. \& Aman P. (2004). Fermentation reduces free asparagine in dough and acrylamide content in bread. Cereal Chemistry 81(5): 650-653.

DOI: https://doi.org/10.1094/CCHEM.2004.81.5.650

Gunlu A. \& Gunlu N. (2014). Taste activity value, free amino acid content and proximate composition of Mountain trout (Salmo trutta macrostigma Dumeril, 1858) muscles. Iranian Journal of Fisheries Science 13(1): 58-72.

Henderson J.W., Ricker R.D., Bidlingmeyer B.A. \& Woodward, C. (2000). Rapid, Accurate, Sensitive, and Reproducible HPLC Analysis of Amino Acids and the Agilent 1100 HPLC.

Household Income and Expenditure Survey (ISBN 978-955702-054-9) (2016), Department of Census and statistics, Battaramulla, Sri Lanka.

IARC. Some industrial chemicals; International Agency for Research on Cancer: Lyon, France, 1994.

Imam M. U., Azmi N. H., Bhanger M. I., Ismail N. \& Ismail M. (2012). Antidiabetic properties of germinated brown rice: A systematic review. Journal of Evidenced Based Complementary and Alternative Medicine 816501. DOI: https://doi.org/10.1155/2012/816501

Inoue K., Shirai T., Ochiai H., Kasao M., Hayakawa K., Kimura M. \& Sansawa H. (2003). Blood-pressure-lowering effect of a novel fermented milk containing g-aminobutyric acid (GABA ) in mild hypertensives. European Journal of Clinical Nutrition 57: 490-495.

DOI: https://doi.org/10.1038/sj.ejcn.1601555

ISO 712:2009. Cereals and cereal products - Determination of moisture content - Reference method

ISO 13903: 2005 Animal feeding stuffs — determination of amino acids content

Jakobs C., Jaeken J. \& Gibson K.M.G. (1993). Inherited disorders of GABA. Journal of Inherited Metabolic Disease 16: 704-715.

DOI: https://doi.org/10.1007/BF00711902

Jayatissa R.L.N., Wickramasinghe W.D. \& Piyasena C. (2014). Food Consumption Patterns in Sri Lanka, Research Report No: 172. Hector Kobbekaduwa Agrarian Research and Training Institute, Colombo 07.

Juliano B.O. \& Villareal C.P. (1993). Grain Quality Evaluation Of World Rices. International Rice Research Institute, Manila, Philippines.

Karladeea D. \& Suriyonga S. (2012). $\gamma$-Aminobutyric acid (GABA) content in different varieties of brown rice during germination. Science Asia 38: 13-17.

DOI: https://doi./10.2306/scienceasia1513-1874.2012.38.013

Kennedy G. \& Burlingame B. (2003). Analysis of food composition data on rice from a plant genetic resources perspective. Food Chemistry 80: 589-596. DOI: https://doi.org/10.1016/S0308-8146(02)00507-1

Kamara J.S., Konishi S., Sasanuma T. \& Abe T. (2010). 
Variation in free amino acid profile among some rice (Oryza sativa L.) cultivars. Breeding Science 60: 46-54.

Kasumyan A.O. (2016). Taste attractiveness of free amino acids and their physicochemical and biological properties (as exemplified by fishes). Journal of Evolutionary Biochemistry and Physiology 52: 271-281. DOI: https://doi.org/10.1134/S0022093016040013

Komatsuzaki N., Tsukahara K. \& Toyoshima H. (2007). Effect of soaking and gaseous treatment on GABA content in germinated brown rice. Journal of Food Engineering 78: 556-560.

DOI: https://doi./10.1016/j.jfoodeng.2005.10.036

Liu L.L., Zhai H.Q. \& Wan J.M.(2005). Accumulation of $\gamma$ aminobutyric acid in giant-embryo rice grain in relation to glutamate decarboxylase activity and its gene expression during water soaking. Cereal Chemistry 82(2):191-196. DOI: https://doi.org/10.1094/CC-82-0191

Liu K., Zheng J. \& Chen F.(2017). Relationships between degree of milling and loss of Vitamin B, minerals, and change in amino acid composition of brown rice. LWTFood Science and Technology 82: 429-436. DOI: https://doi.org/10.1016/j.lwt.2017.04.067.

Liyanaarachchi G.V.V., Mahanama K.R.R., Somasiri H.P.P.S. \& Punyasiri P.A.N. (2018). Development and validation of a method for direct, underivatized analysis of free amino acids in rice using liquid chromatography-tandem mass spectrometry. Journal of Chromatography A 1568: 131-139.

DOI: https://doi.org/10.1016/j.chroma.2018.07.035

Lyon B.G. et al. (11 authors) (1999). Sensory quality of cooked long-grain rice as affected by rough rice moisture content, storage temperature, and storage duration. Cereal Chemistry 76 (1): 56-62. DOI: https://doi.org/10.1094/CCHEM.2000.77.2.259

Martin M. \& Fitzgerald M.A. (2002). Proteins in Rice Grains Influence Cooking Properties!. Journal of Cereal Science 36 (3): 285-294. DOI: https://doi.org/10.1006/jers.2001.0465

Mody I., Dekoninck Y., Otis T.S. \& Soltesz I. (1994). Bringing the cleft at GABA synapses in the brain. Trends in Neuroscience 17: 517-525. DOI: https://doi.org/10.1016/0166-2236(94)90155-4

Mustafa A., Aman P., Andersson R. \& Eldin A.K. (2007). Analysis of free amino acids in cereal products. Food Chemistry 105: 317-324.

DOI: https://doi.org/10.1016/j.foodchem.2006.11.044

Nagaoka H. (2005). Treatment of germinated wheat to increase levels of gaba and ip6 catalyzed by endogenous enzymes. Biotechnology Progress 21: 405-410.
DOI: https://doi.org/10.1021/bp0496777

Ning H., Qiao J., Liu Z., Lin Z., Li G., Wang Q., Wang S. \& Ding Y. (2010). Distribution of proteins and amino acids in milled and brown rice as affected by nitrogen fertilization and genotype. Journal of Cereal Science 52: 90-95. DOI: https://doi:10.1016/j.jcs.2010.03.009.

Nishimura T. \& Kato H. (1988). Taste of free amino acids and peptides. Food Reviews International 4: 175-194. DOI: https://doi.org/10.1080/87559128809540828

Park E.J., Chung J.W., Park Y.J., Chung I.M., Ahn J.K. \& Kim, G.H. (2009). Association analysis of the amino acid contents in rice. Journal of Integrated Plant Biology 51(12): 1126-1137.

DOI: https://doi.org/10.1111/j.1744-7909.2009.00883.x

Park K. \& Oh S. (2007). Production of yogurt with enhanced levels of gamma-aminobutyric acid and valuable nutrients using lactic acid bacteria and germinated soybean extract. Bioresources Technology 98: 1675-1679. DOI: https://doi.org/10.1016/j.biortech.2006.06.006

Rambukwella R., Priyadarshana D. \& Wijesooriya N. (2017). Consumption Pattern and Consumer Preference for Different Rice Varieties in Selected Districts in Sri Lanka, Research Report No: 204, Hector Kobbekaduwa Agrarian Research and Training Institute, Colombo 7, Sri Lanka.

Rita A., Roberta F., Remo B., Mena R. \& Flavio M. (2009). Nutritional and physicochemical characterization of italian rice flours and starches. Food Science of Technology Research 15: 507-518.

DOI: https://doi.org/10.3136/fstr.15.507

Shen S., Wang Y.,, Li M., Xu F., Chai L. \& Bao J. (2015). The effect of anaerobic treatment on polyphenols, antioxidant properties, tocols and free amino acids in white, red, and black germinated rice (Oryza sativa L.). Journal of Functional Foods 19: 641-648.

DOI:https://doi.org/10.1016/j.jff.2015.09.057

World Health Organization (2007). Protein and Amino Acid Requirements in Human Nutrition: report of a Joint FAo/ WHo/UNu Expert Consultation. WHo Technical Report Series no 935.

Xie L., Chen N., Duan B., Zhu Z. \& Liao X. (2008). Impact of proteins on pasting and cooking properties of waxy and non-waxy rice. Journal of Cereal Science 47(2): 372-379. DOI: https://doi.org/10.1016/j.jcs.2007.05.018

Zilic S., Dodig D., Basic Z., Vancetovic J., Titan P., Duric N. \& Tolimir N. (2017). Free asparagine and sugars profile of cereal species: the potential of cereals for acrylamide formation in foods. Food Additives and Contaminants: Part A 34(5): 705-713.

DOI: https://doi.org/10.1080/19440049.2017.1290281 
Supplementary table: Method validation parameters for free amino acid analysis

\begin{tabular}{|c|c|c|c|c|c|c|c|c|c|c|c|}
\hline \multirow[b]{2}{*}{ Amino acid } & \multicolumn{3}{|c|}{ Precision (\% RSD) } & \multicolumn{3}{|c|}{$\%$ Recovery } & \multirow{2}{*}{$\begin{array}{l}\text { Working } \\
\text { range } \\
\mathrm{mg} / 100 \mathrm{~g}\end{array}$} & \multirow{2}{*}{$\begin{array}{c}\% \text { Expanded } \\
\text { Uncertainty } \\
\quad(k=2)\end{array}$} & \multirow[b]{2}{*}{$\mathrm{R}^{2}$} & \multirow{2}{*}{$\begin{array}{c}\mathrm{LOD} \\
\mathrm{mg} / 100 \mathrm{~g}\end{array}$} & \multirow{2}{*}{$\begin{array}{c}\mathrm{LOQ} \\
\mathrm{mg} / 100 \mathrm{~g}\end{array}$} \\
\hline & Low & Mid & High & Low & Mid & High & & & & & \\
\hline Glu & 3.1 & 0.3 & 0.3 & $86 \pm 9$ & $100 \pm 3$ & $103 \pm 4$ & $0.2-100$ & 13 & 0.999 & 0.1 & 0.2 \\
\hline Asp & 7.0 & 1.3 & 2.0 & $99 \pm 8$ & $98 \pm 2$ & $103 \pm 6$ & $0.4-100$ & 13 & 0.999 & 0.2 & 0.4 \\
\hline Asn & 2.3 & 0.1 & 0.2 & $92 \pm 8$ & $93 \pm 2$ & $104 \pm 5$ & $0.4-100$ & 9 & 0.999 & 0.2 & 0.4 \\
\hline Ala & 3.0 & 0.2 & 0.2 & $105 \pm 8$ & $105 \pm 1$ & $107 \pm 6$ & $0.4-100$ & 13 & 0.999 & 0.2 & 0.4 \\
\hline Lys* & 2.1 & 2.3 & 1.3 & $80 \pm 3$ & $85 \pm 1$ & $90 \pm 2$ & $0.3-100$ & 4 & 0.999 & 0.1 & 0.3 \\
\hline Val & 1.3 & 1.2 & 1.4 & $96 \pm 2$ & $93 \pm 2$ & $93 \pm 1$ & $0.2-100$ & 4 & 0.999 & 0.1 & 0.2 \\
\hline Phe & 2.4 & 1.0 & 1.2 & $96 \pm 2$ & $93 \pm 1$ & $95 \pm 1$ & $0.8-100$ & 5 & 0.999 & 0.6 & 0.8 \\
\hline Tyr* & 0.3 & 0.2 & 0.1 & $99 \pm 2$ & $99 \pm 2$ & $98 \pm 2$ & $0.2-100$ & 4 & 0.999 & 0.1 & 0.2 \\
\hline His & 2.6 & 2.0 & 1.4 & $95 \pm 1$ & $95 \pm 1$ & $101 \pm 2$ & $0.2-100$ & 4 & 0.999 & 0.1 & 0.2 \\
\hline Ser & 2.2 & 2.9 & 2.2 & $98 \pm 1$ & $94 \pm 1$ & $100 \pm 3$ & $0.1-100$ & 5 & 0.999 & 0.05 & 0.1 \\
\hline Thr & 2.1 & 2.3 & 1.8 & $94 \pm 1$ & $91 \pm 2$ & $98 \pm 1$ & $0.4-100$ & 6 & 0.999 & 0.2 & 0.4 \\
\hline Pro & 1.3 & 2.1 & 2.1 & $96 \pm 2$ & $98 \pm 1$ & $103 \pm 4$ & $0.2-100$ & 5 & 0.999 & 0.1 & 0.2 \\
\hline Ile & 0.8 & 0.3 & 1.2 & $92 \pm 1$ & $89 \pm 1$ & $92 \pm 4$ & $0.1-100$ & 4 & 0.999 & 0.05 & 0.1 \\
\hline Leu & 2.5 & 2.5 & 1.5 & $80 \pm 2$ & $80 \pm 1$ & $82 \pm 5$ & $0.2-100$ & 5 & 0.999 & 0.1 & 0.2 \\
\hline Gly & 1.6 & 1.2 & 2.9 & $104 \pm 3$ & $98 \pm 2$ & $101 \pm 3$ & $0.4-100$ & 5 & 0.999 & 0.2 & 0.4 \\
\hline Met & 1.2 & 2.8 & 1.9 & $99 \pm 1$ & $99 \pm 1$ & $101 \pm 1$ & $0.1-100$ & 5 & 0.999 & 0.05 & 0.1 \\
\hline Gln & 1.7 & 1.7 & 2.9 & $92 \pm 2$ & $89 \pm 1$ & $97 \pm 1$ & $0.2-100$ & 5 & 0.999 & 0.1 & 0.2 \\
\hline Arg* & 2.6 & 1.5 & 1.3 & $85 \pm 6$ & $87 \pm 2$ & $92 \pm 2$ & $0.2-100$ & 6 & 0.999 & 0.1 & 0.2 \\
\hline $\operatorname{Trp}$ & 2.5 & 3.6 & 0.2 & $106 \pm 3$ & $110 \pm 5$ & $110 \pm 4$ & $0.2-100$ & 8 & 0.999 & 0.1 & 0.2 \\
\hline GABA & 2.7 & 0.8 & 1.1 & $91 \pm 3$ & $85 \pm 1$ & $80 \pm 1$ & $0.4-100$ & 12 & 0.999 & 0.2 & 0.4 \\
\hline
\end{tabular}

LOD: Limit of detection; LOQ: Limit of quantification; $\mathrm{R}^{2}$ : Regression coefficient; RSD: Relative standard deviation; Number of replicates $(\mathrm{n})=6$; Coverage factor $(k)=2$

Low, Mid and High represent, $20 \%, 50 \%$ and $80 \%$ levels of the working range of the method, respectively

* Method performance characteristics were evaluated under matrix matched conditions

Standard deviation of recoveries are given followed by the \pm symbol in the respective cells

Asp: Aspartic acid; Glu: Glutamic acid; Asn: Asparagine; Ser: Serine; Gln: Glutamine; His:Histidine; Gly: Glycine; Thr: Threonine; Arg: Arginine; Ala: Alanine; Tyr: Tyrosine; Val: Valine; Met: Methionine; Trp: Tryptophan; Phe: Phenylalanine; Ile: Isoleucine; Leu:Leucine; Lys: Lysine; Pro: Proline; GABA: Gamma amino butyric acid 